\title{
Comparison of Concanavalin a-Induced Murine Autoimmune Hepatitis Models
}

\author{
Tinghong Ye ${ }^{a}$ Tingting Wang ${ }^{a}$ Xiaoxue Yang ${ }^{a}$ Xiaoli Fana Maoyao Wen ${ }^{a}$ \\ Yi Shen ${ }^{\mathrm{a}}$ Xiaotan Xia Ruoting Men ${ }^{\mathrm{a}, \mathrm{b}} \quad$ Li Yang $^{\mathrm{a}}$ \\ aLaboratory of Liver Surgery and Division of Gastroenterology \& Hepatology, State Key Laboratory of \\ Biotherapy/Collaborative Innovation Center for Biotherapy, West China Hospital, Sichuan University, \\ Chengdu, bepartment of Biostatistics, JC school of Public Health and Primary Care, Faculty of \\ Medicine, The Chinese University of Hong Kong, China
}

\section{Key Words}

Autoimmune hepatitis (AIH) - Concanavalin A (ConA) - Mouse models • Immune cells • Cytokines

\begin{abstract}
Background/Aims: Autoimmune hepatitis (AIH) is a chronic necroinflammatory disease of the liver whose pathogenic mechanisms have not yet been elucidated. Moreover, the current treatment used for the vast majority of AIH patients is largely dependent on immunosuppressant administration and liver transplantation. However, research on the pathogenesis of AIH and effective new treatments for AIH have been hampered by a lack of animal models that accurately reproduce the human condition. Methods: AIH models created by concanavalin A (ConA) injections at different times and doses. The levels of ALT, AST, LDH and inflammatory cytokines were examined at various times after $20 \mathrm{mg} / \mathrm{kg}$ ConA was administered by ELISA using commercially available kits. Moreover, liver pathological changes were observed by flow cytometry (FCM) and H\&E staining. Results: Our experiments demonstrated that the levels of ALT, AST, LDH and several inflammatory cytokines, including TNF- $\alpha$, IFN- $\gamma$, and IL6 , were higher in the $20 \mathrm{mg} / \mathrm{kg} 12 \mathrm{~h}$ ConA group than in the other groups. Importantly, the numbers of activated $\mathrm{CD} 4^{+}$and $\mathrm{CD} 8^{+} \mathrm{T}$ lymphocytes in the blood, spleen and liver were calculated. These results showed that ConA ( $20 \mathrm{mg} / \mathrm{kg}$ for $12 \mathrm{~h}$ )-induced hepatitis was similar to that in clinical AIH patients. Furthermore, we found that the number of MDSCs in the blood was significantly increased in the ConA (20 mg/ $\mathrm{kg}$ for $12 \mathrm{~h}$ ) group compared with controls. Our findings indicated that ConA ( $20 \mathrm{mg} / \mathrm{kg}$ for $12 \mathrm{~h}$ )-induced hepatitis could be used as an experimental murine model that mirrors most of the pathogenic properties of human type I AIH. Conclusion: This model [ConA ( $20 \mathrm{mg} / \mathrm{kg}$ for $12 \mathrm{~h}$ )] provides a valuable tool for studying $\mathrm{AIH}$ immunopathogenesis and rapidly assessing novel therapeutic approaches.
\end{abstract}

T. Ye and T. Wang contributed equally to this work. 


\section{Introduction}

Autoimmune hepatitis (AIH) is a chronic necroinflammatory disease of the liver with unclear etiology. AIH mainly affects patients and rapidly leads to cirrhosis and end-stage-liver disease if left untreated [1]. It is characterized serologically by increased aminotransferase levels, interface hepatitis, hypergammaglobulinemia with high IgG levels and the presence of characteristic autoantibodies [2, 3]. AIH is historically classified as type 1 or type 2 on the basis of the autoantibody profile and according to seropositivity: AIH-1 is characterized by the presence of anti-smooth muscle and/or anti-nuclear (anti-SMA/ANA) autoantibodies, and $\mathrm{AIH}-2$ is characterized by the presence of liver kidney microsomal antibody type 1 (antiLKM-1) and/or anti-liver cytosol type 1 (anti-LC1) autoantibodies [4-6]. The latter is mainly a pediatric condition and has a higher risk of acute liver failure [7]. AIH is a worldwide health problem and a significant cause of mortality; it has been estimated that AIH has an annual incidence of approximately 2 in 100, 000 individuals and a prevalence of 15 cases per 100 , 000 persons worldwide [8]. Without treatment, nearly $50 \%$ of patients with severe AIH die in approximately 5 years $[9,10]$. The incidence rate is also different between men and women. It has been reported that women are more vulnerable to AIH [11]. Standard clinical therapy for AIH consists of a combination of corticosteroids and azathioprine and is the mainstay therapy for AIH [2]. Despite the availability of this effective treatment, AIH also poses therapeutic problems. Patients are commonly treated with steroids, but this therapy is not effective in all cases; more than $10-20 \%$ of AIH patients are refractory $[2,12]$. Furthermore, the prolonged use of steroids may cause significant side effects, such as immunosuppression, osteoporosis, and sodium retention, and the discontinuation of steroid treatment is followed by disease relapse in most patients [13-15]. Considering these factors, it is significantly important to develop new, safe and effective drugs. However, the development of novel therapeutic strategies has long been hampered by a lack of valid animal models. Animal models are the basis for drug discovery and development. Therefore, a good preclinical animal model that can replicate the main features of AIH is urgently needed.

AIH is triggered by autoreactive T cells. Animal models are needed to elucidate the early pathogenic events in this process, namely, the priming of autoreactive T cells [16]. Many animal models for AIH have been developed since the early 1970s [8]. The early models of AIH were based on the administration of crude liver homogenates of heterologous origin and complete Freund's adjuvant, with no knowledge of the target antigens responsible for the disease $[8,17,18]$. The second phase began in 1983 when Kuriki et al. established transient hepatitis in mice by immunizing them with syngeneic liver homogenates or liver-specific lipoproteins with polysaccharides from Klebsiella pneumonia [19]. Then, many follow-up studies used inbred or neonatal thymectomy mice to establish the T cell-responsive AIH model $[20,21]$. During the last 20 years, several animal models of AIH have been developed [22-25]. For example, an alternative model of AIH was created by vaccinating mice with dendritic cells (DCs) loaded with well-differentiated murine hepatocellular carcinoma cells (Hepa1-6) and administering interleukin-12 [26]. Moreover, a recent study has reported that low and transient expression of transgenic IL-12 in hepatocytes could cause a loss of tolerance to hepatocellular antigens that leads to chronic hepatitis resembling human type 1 AIH [12].In addition, murine ConA-induced AIH may be prevented by the IL-12 antibody and exacerbated by exogenous IL-12 [27].

Although several murine models of AIH have been described, none of them are completely satisfactory [28]. As the most commonly used AIH research model, ConA-induced hepatitis is a well-established T cell-mediated murine model that mimics human AIH. ConA is a type of lectin that is purified from the crude extract of Canavalia ensiformis seeds. It can agglutinate blood erythrocytes and predominantly stimulates T cells. In addition, immune cells are activated after a ConA injection; many cytokines are released and cause activated lymphocyte infiltration to aggravate liver injury [29]. Moreover, the ConA AIH model is easy to generate, inexpensive, convenient and replicable [30]. Therefore, this model is well- 
Ye et al.: Con a-Induced AIH in Mice

established in mice for investigating T cell- and macrophage- dependent liver injuries, which closely mirror most of the pathogenic properties of AIH patients [31].

The absence of valid animal AIH models is considered to be the main reason for the lack of a simple and efficient cure. Drug candidate activity could be evaluated rapidly by using an optimal ConA AIH model. The aim of this study was to establish a unified standard model of ConA AIH by comparing ConA injections at different times and doses.

\section{Materials and Methods}

AIH patients and healthy donors

A total of 12 peripheral blood samples were obtained from patients with AIH between May 2016 and September 2016 at the Division of Gastroenterology \& Hepatology, West China Hospital, Sichuan University (Sichuan, China). Ten peripheral blood samples were obtained from healthy volunteers for use as normal controls. The present study was approved by the Ethics Committee of West China Hospital, Sichuan University, and written informed consent was obtained from each subject. Table 1 shows the clinical characteristics of the AIH patients who were included in the study.

\section{Animals}

C57BL/6 female mice (8-12 weeks; 20-25 g) were obtained from Beijing HFK Bioscience Co., Ltd., Beijing, China. The mice were housed in a specific-pathogen-free (SPF) facility with a consistent room temperature and humidity. They were provided with free access to standard laboratory chow and water for one week before the experiments. All animal experiments were approved by the Institutional Animal Care and Treatment Committee of Sichuan University in China (Permit Number: 20161208).

\section{Experimental design}

First, the mice were intravenously injected with ConA at different concentrations ranging from 2.5 to $25 \mathrm{mg} / \mathrm{kg}$ for $18 \mathrm{~h}$ to test their survival rates. To evaluate ConA-induced AIH models, the mice were divided into three groups 1) Mice were given a single intravenous injection of normal saline as a vehicle control. 2) Mice were given a single intravenous injection of ConA (Sigma-Aldrich, St. Louis, MO) at a dose of $20 \mathrm{mg} /$ kg body weight and were sacrificed at various times ( $2 \mathrm{~h}, 4 \mathrm{~h}, 6 \mathrm{~h}, 8 \mathrm{~h}$ and $12 \mathrm{~h}$ ) after ConA administration. 3) Mice were given a single intravenous injection of ConA at a dose of $15 \mathrm{mg} / \mathrm{kg}$ body weight and were sacrificed $12 \mathrm{~h}$ after ConA administration.

\section{Liver function and cytokine assay}

Retro-orbital blood samples were collected from the mice. The plasma was separated by centrifugation at $300 \mathrm{~g}$ for $10 \mathrm{~min}$. ALT and AST levels were measured by automatic dry biochemical analyzer (Hitachi Auto Analyzer 7170, Japan). The levels of TNF- $\alpha$, IFN- $\gamma$ and IL-6 in the murine plasma were analyzed by ELISA using commercially available kits (eBioscience, San Diego, CA) according to the manufacturer's instructions.

\section{Histopathology assay}

Liver tissues were harvested after intravenous ConA administration. Liver samples were fixed in $4 \%$ buffered paraformaldehyde for $48 \mathrm{~h}$. Sections (4-5 $\mu \mathrm{m}$ ) on slides were deparaffinized with xylene, rehydrated with decreasing concentrations of ethanol, and stained with hematoxylin and eosin (H\&E). Then, all sections were graded blindly under a light microscope according to the following criteria: 0 , none; 1 , individual cell necrosis; 2, $\leq 30 \%$ lobular necrosis; $3, \leq 60 \%$ lobular necrosis; and 4, >60\% lobular necrosis [9].

\section{Flow cytometry (FCM) analysis}

Venous blood was collected aseptically from patients and healthy volunteers. Red blood cells in the peripheral blood and spleens were lysed and washed twice with phosphate-buffered saline (PBS). In addition, single-cell suspensions of blood, liver, and spleen were obtained $12 \mathrm{~h}$ after ConA administration by using mechanical and enzymatic dispersion as described previously [32]. In general, the peripheral blood, spleen and liver were harvested. Red blood cells in the peripheral blood and spleen were lysed. A singlecell suspension of the liver was mechanically disrupted and then enzymatically digested with $1 \mathrm{mg} / \mathrm{mL}$ 
collagenase I. Then, $1 \times 10^{6}$ freshly prepared cells were suspended in $100 \mu \mathrm{l}$ of PBS and stained with different combinations of fluorochrome-coupled antibodies for CD11b, CD8, CD4, CD69 and Gr-1. The cells were collected by FCM, and the data were analyzed using FlowJo software.

\section{Statistical analysis}

All experiments were performed at least three times. The results are expressed as the mean $\pm \mathrm{SD}$, and $P$ values for comparisons were determined by 2 -tailed Student's $t$ tests. Statistically significant $p$ values are labeled as follows: ${ }^{*} p<0.05 ;{ }^{* *} p<0.01 ;{ }^{* * *} p<0.001 .{ }^{*} p<0.05 ;{ }^{\# \#} p<0.01$; and ${ }^{\# \# \#} p<0.001$.

\section{Results}

Clinical and laboratory features of AIH patients at the time of the study

Similar to many other autoimmune diseases, AIH is prevalent in women. Twelve consecutive patients with AIH-1 [median age $=50.5$ years (range $=41-53.5$ years), $91.7 \%$ female] were enrolled between May 2016 and September 2016; ten healthy volunteers served as healthy controls [HCs; median age $=42$ years (range $=27-54$ years), $80 \%$ female]. Patient clinical and laboratory features are summarized in Table 1 . All patients had high aminotransferase gammaglutamyl transpeptidase (GGT), bilirubin, gamma globulin and immunoglobulin $\mathrm{G}$ (IgG) levels. As shown in Table 1, ANAs were present in all 12 patients, and AMAs were present in 5 patients (41.75). At diagnosis, all patients met the diagnostic criteria of the International Autoimmune Hepatitis Group [33].

\section{Percentages of T cell populations}

$\mathrm{T}$ cell-mediated immune responses

Table 1. Clinical characteristics of the patients and healthy subjects who were recruited

\begin{tabular}{|c|c|}
\hline Characteristics & Amount \\
\hline Sex (Female, N\%) & 12 (91.7\%) \\
\hline Age (years) & $50.5(41.0,53.5)$ \\
\hline \multicolumn{2}{|c|}{ Liver function indexes } \\
\hline TB $(\mu \mathrm{mol} / \mathrm{L})$ & $37.6(9.6,137.6)$ \\
\hline DB $(\mu \mathrm{mol} / \mathrm{L})$ & $27.0(6.4,112.2)$ \\
\hline ALB $(\mathrm{g} / \mathrm{L})$ & $37.0(34.4,42.9)$ \\
\hline GLB (g/L) & $42.6(37.1,47.8)$ \\
\hline $\operatorname{ALT}(\mathrm{IU} / \mathrm{L})$ & $255.5(144.8,438.8)$ \\
\hline AST (IU/L) & $375.0(180.0,568.2)$ \\
\hline $\operatorname{ALP}(\mathrm{IU} / \mathrm{L})$ & $144.0(123.5,155.0)$ \\
\hline GGT (IU/L) & $135.0(61.3,260.3)$ \\
\hline \multicolumn{2}{|l|}{ Immunoglobulin } \\
\hline $\operatorname{IgG}(\mathrm{g} / \mathrm{L})$ & $26.3(22.8,32.8)$ \\
\hline $\operatorname{IgM}(\mathrm{mg} / \mathrm{L})$ & $2660(1887.5,3975.0)$ \\
\hline \multicolumn{2}{|l|}{ Autoantibody } \\
\hline ANA $(+, N \%)$ & 12 (100.0\%) \\
\hline AMA (+, N\%) & $5(41.7 \%)$ \\
\hline
\end{tabular}
are thought to play a key role in causing of autoimmune liver damage. Therefore, we assessed the $\mathrm{T}$ cells in the peripheral blood from $\mathrm{AIH}$ patients and HCs by FCM using CD3, CD4 and CD8 antibodies. As shown in Fig. 1a, the results showed that the percentage of $\mathrm{CD}^{+} \mathrm{CD}^{+} \mathrm{T}$ cells was higher in AIH patients than in HCs. The levels of activated $\mathrm{CD} 4^{+} \mathrm{T}$ cells in the HC group were reduced by $\sim 1.6-$ fold compared with those in the AIH group. Furthermore, using the FCM data, we found an $\sim 1$.4-fold reduction in $\mathrm{CD}^{+}{ }^{+} \mathrm{CD}^{+} \mathrm{T}$ cell infiltration in the AIH group compared with that in the control group (Fig. 1b).

Dose dependence of ConA-induced liver injury

$\mathrm{AIH}$ is chronic and more prevalent in females and genetically predisposed individuals. In fact, the gender ratio is $3.6: 1$, with women being more

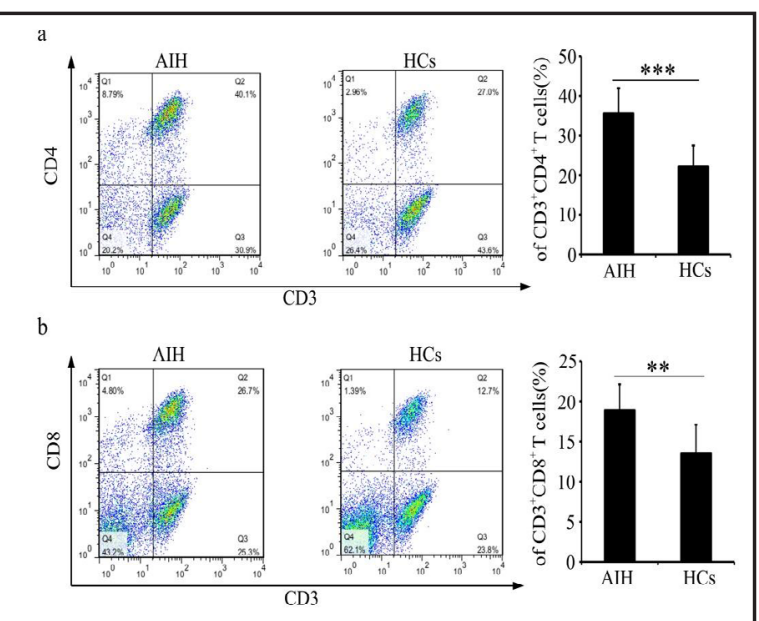

Fig. 1. Analysis of T cells from AIH patients and HCs. (a) Single-cell suspensions prepared from the peripheral blood of AIH patients and HCs (HCs represent healthy human controls) were analyzed for the presence of $\mathrm{CD}^{+} \mathrm{CD}^{+}$cells by FCM. Bars show the mean $\pm S D$; ${ }^{* * *} p<0.001$. (b) Singlecell suspensions prepared from the peripheral blood of AIH patients and HCs were analyzed for the presence of $\mathrm{CD}^{+}{ }^{+} \mathrm{CD} 3^{+}$cells by FCM. Bars show the mean $\pm \mathrm{SD} ;{ }^{* *} \mathrm{p}<0.01$. 
affected by AIH than men [34]. In addition, mice with a Th2-biased immune response, such as BALB/c inbred mice, require higher ConA doses of up to $>30 \mathrm{mg} / \mathrm{kg}$ body weight to induce AIH. In contrast, animals with an immune response of more Th1-like $\mathrm{T}$ helper cells, such as C57BL/6 mice, are more susceptible to ConA and typically require only approximately $15-20 \mathrm{mg} / \mathrm{kg}$ body weight [35]. Therefore, we chose female C57/6 mice to our study. First, we examined mice that were i.v. injected with ConA at different concentrations of 5-25 $\mathrm{mg} / \mathrm{kg}$ for $18 \mathrm{~h}$. As shown in Table 2, the 5 to $10 \mathrm{mg} / \mathrm{kg}$ doses of ConA at $18 \mathrm{~h}$ were safe for the mice, whereas the 15 $\mathrm{mg} / \mathrm{kg} 18 \mathrm{~h}$ dose induced death $20 \%$ of the mice. Thus, we used $12 \mathrm{~h}$ as the longest time for our study.

\section{Hepatic injury after ConA administration}

We first successfully developed mouse models of AIH by using ConA treatment for different times. As illustrated in Fig. 2a, the ConA-treated groups had significantly higher spleen indexes than the control group. (The spleen index was calculated as the relative spleen weight ratio (spleen weight/body weight) for the experimental animals and controls). However, there were no significant differences in the liver indexes between the ConA-treated group and the control group (Fig. 2b). Interestingly, as shown in Fig. 2c, the ConA-treated groups had significantly higher kidney indexes than the control group. Moreover, compared with the control-treated mice, the mice injected with ConA developed acute hepatitis as indicated by their elevated serum ALT and AST levels. As shown in Fig. 3a-c, the serum levels of ALT, AST and LDH in mice were elevated significantly after ConA injection at $2 \mathrm{~h}$, and reached their peak levels at $12 \mathrm{~h}$. Moreover, the levels of ALT, AST and LDH in the group treated with ConA $20 \mathrm{mg} / \mathrm{kg}$ for $12 \mathrm{~h}$ were higher than those in other groups. Furthermore, light microscopy showed dramatic inflammatory cell infiltration, massive hepatocyte necrosis, blood vessel congestion and dilatation and disordered hepatic sinusoid structures in ConA-treated mice. The pathological scores showed that liver injury in the ConA (20 mg/kg for $12 \mathrm{~h}$ ) group was significantly more severe than that in the other groups (Fig. $4 \mathrm{~h}$ ). Therefore, the pathological evidence demonstrated that this model had the characteristics of AIH.
Table 2. Various concentrations of ConA ranging from 5 to $25 \mathrm{mg} / \mathrm{kg}$ for different times, The subscript represents the number of deaths in mice

\begin{tabular}{lccc}
\hline Doses $\$ Time & $8 \mathrm{~h}$ & $12 \mathrm{~h}$ & $18 \mathrm{~h}$ \\
\hline $5 \mathrm{mg} / \mathrm{kg}$ & $10_{0}$ & $10_{0}$ & $10_{0}$ \\
$10 \mathrm{mg} / \mathrm{kg}$ & $10_{0}$ & $10_{0}$ & $10_{0}$ \\
$15 \mathrm{mg} / \mathrm{kg}$ & $10_{0}$ & $10_{0}$ & $10_{2}$ \\
$20 \mathrm{mg} / \mathrm{kg}$ & $10_{0}$ & $10_{1}$ & $10_{4}$ \\
$25 \mathrm{mg} / \mathrm{kg}$ & $10_{1}$ & $10_{3}$ & $10_{6}$ \\
\hline
\end{tabular}

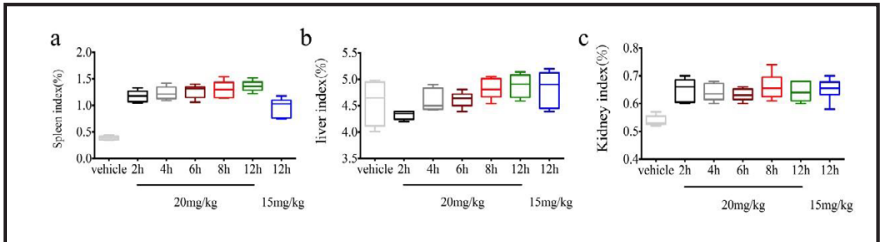

Fig. 2. Organ indexes in ConA-induced hepatitis. Mice ( $n=5$ for each group) were injected with ConA (20 mg/kg) at different times. Each group was sacrificed at the following time points: $2 \mathrm{~h}$, $4 \mathrm{~h}, 6 \mathrm{~h}, 8 \mathrm{~h}, 10 \mathrm{~h}$ and $12 \mathrm{~h}$ after ConA injection, and the other group was injected with ConA for $12 \mathrm{~h}$. (a) Spleen index of the different groups. (b) Liver index of the different groups. (c) Kidney index of the different groups.

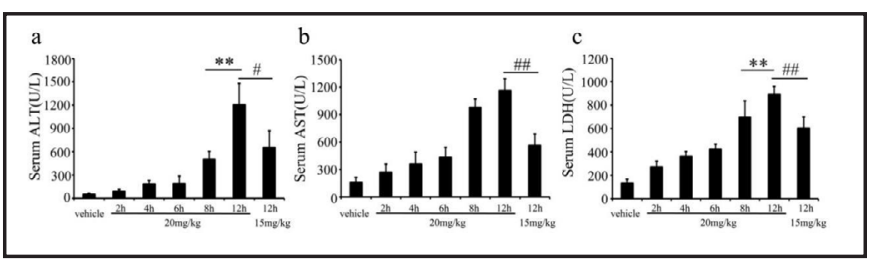

Fig. 3. ALT,$A S T$ and LDH levels were determined in ConAinduced hepatitis. (a) Serum transaminase activities (ALT) were determined at different time after intravenous injection of 20 $\mathrm{mg} / \mathrm{kg}$ or $15 \mathrm{mg} / \mathrm{kg}$ ConA into C57BL/6 mice. (b) AST levels were determined at different times after intravenous injection of $20 \mathrm{mg} / \mathrm{kg}$ or $15 \mathrm{mg} / \mathrm{kg}$ ConA into C57BL/6 mice. (c) Serum LDH levels were determined at different times after intravenous ${ }^{*} \mathrm{p}<0.05 ;{ }^{* *} \mathrm{p}<0.01 ;{ }^{\#} \mathrm{p}<0.05$; ${ }^{\# \#} \mathrm{p}<0.01$. injection of $20 \mathrm{mg} / \mathrm{kg}$ or $15 \mathrm{mg} / \mathrm{kg}$ ConA into C57BL/6 mice. 
Fig. 4. Liver damage after ConA treatment. Representative H\&E sections of the liver. (a) Vehicle control group. (b) $20 \mathrm{mg} / \mathrm{kg} 2 \mathrm{~h}$ group. (c) 20 $\mathrm{mg} / \mathrm{kg} 4 \mathrm{~h}$ group. (d) $20 \mathrm{mg} / \mathrm{kg} 6 \mathrm{~h}$ group. (e) 20 $\mathrm{mg} / \mathrm{kg} 8 \mathrm{~h}$ group. (f) $20 \mathrm{mg} / \mathrm{kg} 12 \mathrm{~h}$ group. (g) $15 \mathrm{mg} / \mathrm{kg} 12 \mathrm{~h}$ group. (h)Pathological scores of the different groups. ${ }^{*} \mathrm{p}<0.05 ;{ }^{* *} \mathrm{p}<0.01$; ${ }^{*} \mathrm{p}<0.05$; \#\# $\mathrm{p}<0.01$.

Changes in the expression levels of relevant cytokines

ConA-induced hepatitis is associated with the production of various proinflammatory cytokines. Therefore, we

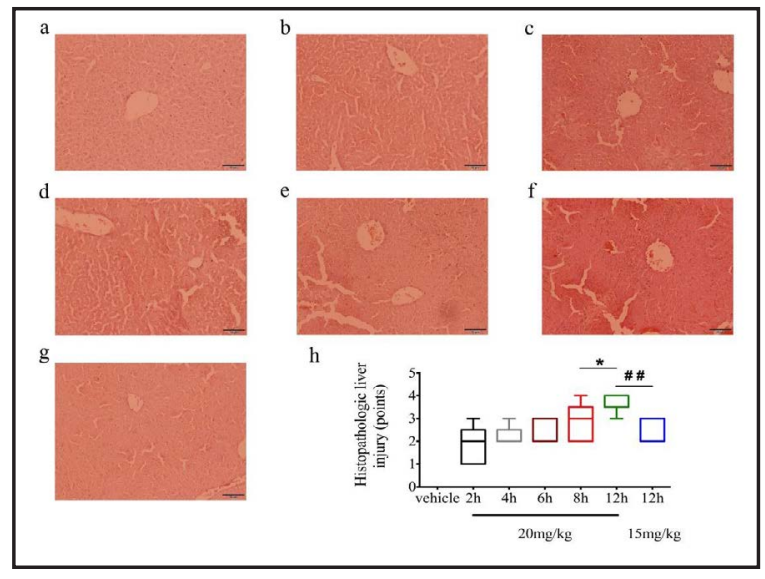
next measured a series of cytokines, including TNF- $\alpha$, IFN- $\gamma$, and IL-6, by ELISA. As shown in Fig. 5a-c, after ConA administration, the levels of the pro-inflammatory cytokines TNF- $\alpha$, IFN- $\gamma$, and IL- 6 were elevated in the plasma compared with those in the control groups. Moreover, TNF- $\alpha$ and IL-6 levels robustly increased after ConA $(20 \mathrm{mg} / \mathrm{kg})$ administration. Moreover, previous data revealed that the

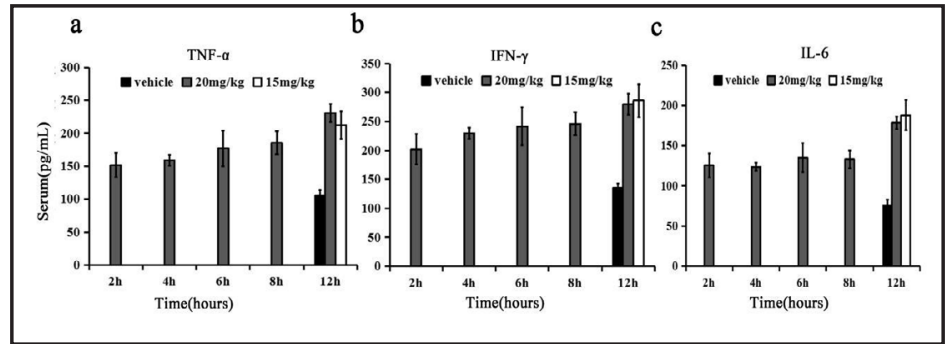

Fig. 5. ELISA analysis of cytokines in ConA-induced hepatitis. C57BL/6 mice $(n=5)$ were injected with PBS or ConA at different times and doses. Blood was collected after the indicated times, and serum cytokine levels were determined by ELISA.

ConA (20 mg/kg for $12 \mathrm{~h}$ ) group was significantly more severe than that in the other groups. Therefore, we use the ConA (20 $\mathrm{mg} / \mathrm{kg}$ for $12 \mathrm{~h}$ ) group for the next experiments.

\section{ConA-induced inflammatory cell recruitment and activation}

AIH is caused by activated T lymphocytes that infiltrate and destroy the liver parenchyma, thus leading to liver injury. To further confirm the role of T cells in the development of AIH in our model, lymphocytes were isolated from the blood after ConA treatment $(20 \mathrm{mg} / \mathrm{kg}$ for $12 \mathrm{~h})$. We used the CD4 and CD69 antibodies to identify active $\mathrm{CD} 4^{+}$ T cells. Fig. 6 shows that after treatment with ConA, the number of active $\mathrm{CD}^{+} \mathrm{T}$ cells was increased in the blood. Notably,

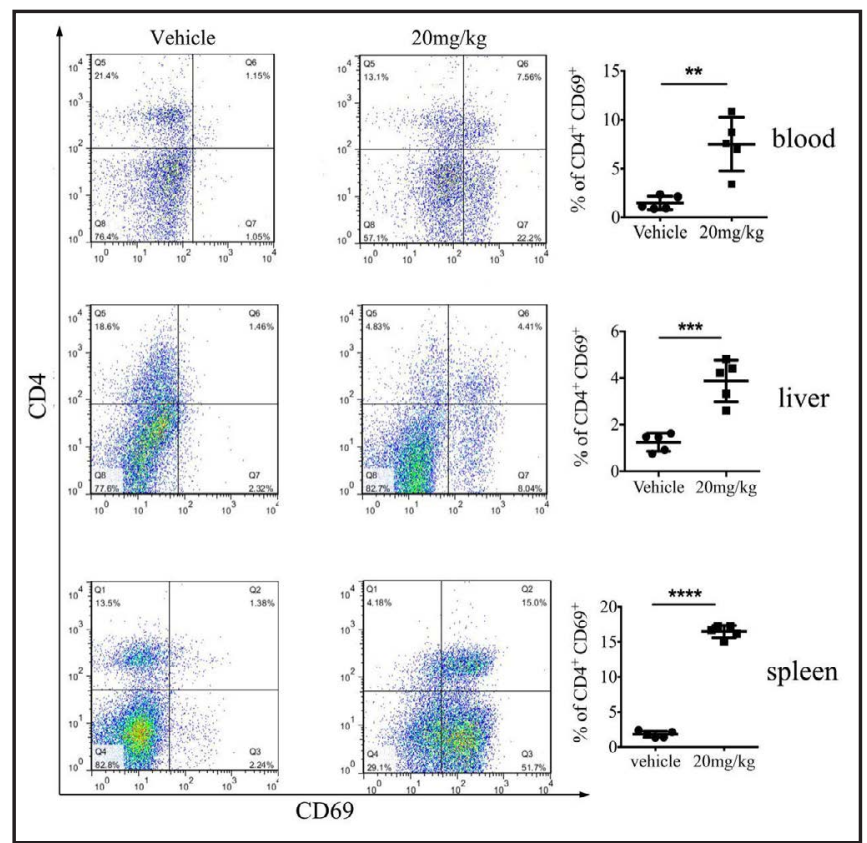

Fig. 6. Effects of ConA on host immunity. Single-cell suspensions prepared from the peripheral blood, livers and spleens of the ConA $20 \mathrm{mg} / \mathrm{kg} 12 \mathrm{~h}$ group and the vehicle group were analyzed by FCM for the presence of $\mathrm{CD} 4{ }^{+} \mathrm{CD} 69^{+}$cells. Bars show the mean \pm SD; ${ }^{* *} \mathrm{p}<0.01,{ }^{* * *} \mathrm{p}<0.001$. 
Fig. 7. Active $C D 8^{+} \mathrm{T}$ cells were determined after ConA treatment. Single-cell suspensions prepared from the peripheral blood, livers and spleens of the ConA 20 $\mathrm{mg} / \mathrm{kg} 12 \mathrm{~h}$ group and the vehicle group were analyzed by FCM for the presence of $\mathrm{CD} 8^{+} \mathrm{CD}_{69}{ }^{+}$cells. Bars show the mean $\pm \mathrm{SD}$; ${ }^{* *} \mathrm{p}<0.01,{ }^{* * *} \mathrm{p}<0.001$.

the liver infiltration of active $\mathrm{CD}^{+}$ $\mathrm{T}$ lymphocytes was increased in the ConA-treated group compared with that in the control groups. Similarly, the active $\mathrm{CD} 4^{+} \mathrm{T}$ lymphocytes in the spleen were significantly increased in the ConA group. Moreover, we investigated the levels of active $C D 8^{+} \mathrm{T}$ lymphocytes in organs. As shown in Fig. 7, active $C D 8^{+} \mathrm{T}$ lymphocyte infiltration was higher in the ConA-treated group than in the control groups. Taken together, these results implied that intravenous injection of ConA into mice could increase the number of activated T cells. These results were consistent with those from the clinical AIH patients.

\section{ConA increased the number of myeloid- derived suppressor cells (MDSCs) \\ MDSCs are a}

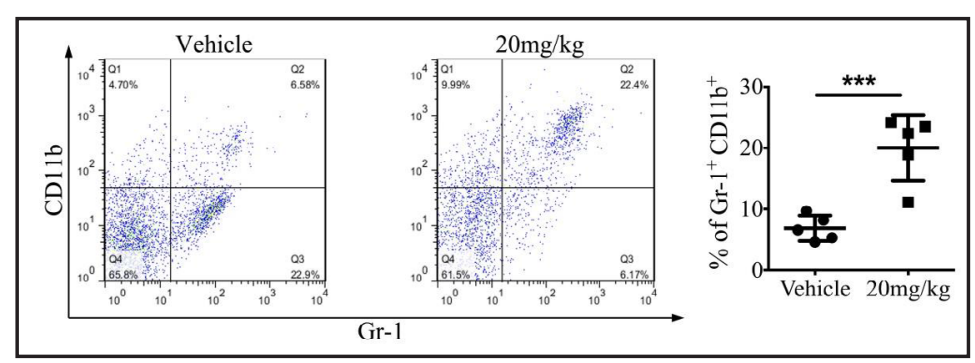

Fig. 8. Gr- $1^{+} \mathrm{CD} 11 \mathrm{~b}^{+}$myeloid cells were increased after ConA treatment. Gr $1^{+} \mathrm{CD} 11 \mathrm{~b}^{+}$cells were gated and analyzed by FCM for the presence of MDSCs. Statistical results from each group. Compared with vehicle treatment, treatment with ConA $20 \mathrm{mg} / \mathrm{kg} 12 \mathrm{~h}$ significantly increased the number of MDSCs. Values represent the mean $\pm \operatorname{SD}(\mathrm{n}=5) ;{ }^{* * *} \mathrm{p}<0.001$.

heterogeneous cell population consisting of immature myeloid cells and myeloid progenitor cells that can suppress $\mathrm{T}$ cell responses by a variety of mechanisms [32]. Therefore, we measured the number of MDSCs, which were identified as CD11 $\mathrm{b}^{+}$and Gr- $1^{+}$double-positive myeloid cells by FCM, to investigate the blood myeloid cell infiltration. As shown in Fig. 8, the percentage of MDSCs was significantly higher in the ConA-treated group than in the control group.

\section{Discussion}

AIH is a chronic inflammatory liver disease of unknown etiology and is associated with interface hepatitis, the presence of autoantibodies and regulatory T cell (Tregs) dysfunction [36]. Moreover, AIH severity varies widely among patients; some cases will develop confluent hepatocellular necrosis that leads to acute liver failure or advanced liver cirrhosis that requires liver transplantation [12]. Therefore, AIH is a complex polygenic disease that remains a major clinical challenge, and novel effective therapies need to be explored for clinical use [37]. Furthermore, proper animal models that replicate human AIH are required to achieve this goal.

ConA can activate $\mathrm{T}$ cells to secrete cytokines that cause liver injury. Therefore, ConAinduced hepatitis is used as a mouse model of immune-mediated liver injury and resembles 
AIH in humans [38].In this study, we used ConA to induce AIH in mice and established a unified standard model of the ConA AIH model. The levels of ALT, AST and LDH increased from $2 \mathrm{~h}$ and reached their peaks at $12 \mathrm{~h}$. Moreover, the pathological scores were significantly higher in the ConA $20 \mathrm{mg} / \mathrm{kg} 12 \mathrm{~h}$ group than in the other groups. It is a commonly thought that hepatitis progression is associated with pro-inflammatory cytokines, such as TNF- $\alpha$, IL- 6 and IFN- $\gamma[37,39]$. Therefore, we measured the serum levels of TNF- $\alpha$, IL- 6 and IFN- $\gamma$. The levels of these cytokines increased after ConA treatment and were highest at $12 \mathrm{~h}$.

TNF- $\alpha$ plays a major role in the pathogenesis of ConA-induced AIH. In the plasma, TNF- $\alpha$ first peaked after $1 \mathrm{~h}$ in the ConA model of BALB/c mice [30]. Moreover, in the Male Naval Medical Research Institute (NMRI) ConA model in albino mice [40], the levels of TNF- $\alpha$ peaked $2 \mathrm{~h}$ after ConA injection. Furthermore, an earlier report showed that the plasma levels of TNF- $\alpha$ were highest at $2 \mathrm{~h}$ after an LPS challenge in neonatal mice challenged with $25 \mathrm{mg} / \mathrm{kg} \mathrm{S}$. enteriditis [41]. In addition, in a type 1 diabetes model in NOD mice, in vivo injection with anti-CD3 mAb induced T cells to release several cytokines, such as TNF- $\alpha$ and IFN- $\gamma$, which appear in the circulation with different kinetics. Because the release of TNF- $\alpha$ from mononuclear cells is faster than that of IFN- $\gamma$, TNF- $\alpha$ was found in the blood at $2 \mathrm{~h}$ but not at $6 \mathrm{~h}$ after administration [42]. However, in our study, we did not examine the levels of TNF- $\alpha 1 \mathrm{~h}$ after ConA injection. TNF- $\alpha$ levels should peak $1 \mathrm{~h}$ after ConA injection in female C57/6 mice. The reason for this discrepancy is not known, although different strains of mice and environmental factors may be involved.

During $\mathrm{AIH}$, self-tolerance is defective and results in $\mathrm{T}$ lymphocytes dysfunction, including highly activated CD4 and CD8 T cells, which mediate autoimmune liver injury [38, 43]. These findings suggest that $\mathrm{CD}^{+} \mathrm{T}$ helper $(\mathrm{Th})$ cells were involved in liver injury. In our research, $\mathrm{T}$ cell-mediated liver injury was detected in the group receiving intravenously injected ConA (20 mg/kg $12 \mathrm{~h})$. Previous studies have indicated that immune cells are activated after ConA injection and that, as a result, a number of cytokines that aggravate liver injury are released [44].

The $\mathrm{CD} 11 \mathrm{~b}^{+} \mathrm{Gr}-1^{+} \mathrm{MDSC}$ are receiving increasing attention as one of the main regulatory cells of the immune system [45]. The frequency of MDSCs has been reported to be involved in the immune response, not only in inflammation associated with cancer but also in AIH [43]. Moreover, the frequency of MDSCs in AIH patients has been reported to be significantly higher than that in HCs. Moreover, the frequency of MDSCs in the peripheral blood has been positively correlated with ALT and AST levels in AIH patients [43]. Furthermore, administration of ConA resulted in an increase in both the percentage and absolute number of hepatic MDSCs. ConA+ cannabidiol treatment resulted in further robust induction of MDSCs when compared to the ConA+vehicle treatment group [43]. In this study, we found that the number of MDSCs in the peripheral blood of ConA-treated mice was higher than that in the vehicle-treated mice. These results were consistent with the AIH clinical data. Therefore, MDSCs are important for ConA-induced AIH and may provide a possible method for immune intervention.

\section{Conclusion}

In summary, this study provides a reliable mouse model of ConA-induced AIH. The ConA $(20 \mathrm{mg} / \mathrm{kg} 12 \mathrm{~h}$ ) animal model, which is a typical T cell and marcrophage-dependent model, mimics the mechanisms and characteristics of clinical AIH. Therefore, we believe this is a good mouse model for studying the mechanisms of AIH and developing new therapeutic drugs.

\section{Abbreviations}

AIH (Autoimmune hepatitis); ConA (Concanavalin A); FCM (Flow cytometry); AST (Aspartate aminotransferase); ALT (Alanine aminotransferase); LDH (Lactate dehydrogenase); 


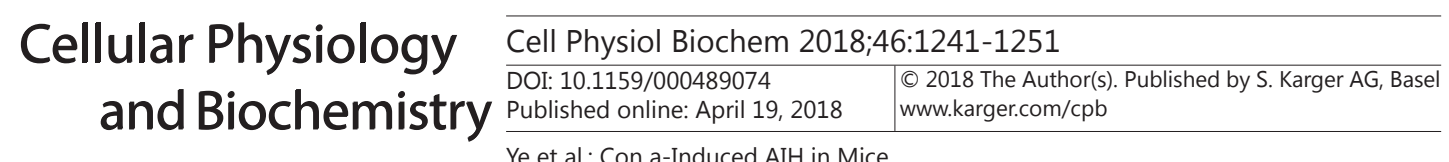

Ye et al.: Con a-Induced AIH in Mice

MDSCs (myeloid-derived suppressor cell); HE (hematoxylin-eosin); PBS (Phosphate-buffered saline).

\section{Acknowledgements}

We are grateful to Weihan Yang at Merck Millipore for her helpful suggestions regarding this manuscript. We also thank Chengdu peng shida experimental supplies co. LTD for cytokine testing. This research was supported by the National Natural Science Foundation of China (81770568 and 81570554) and the Key Project of the Science \& Technology Department of Sichuan Province (Grant No. 2017JY0071).

\section{Disclosure Statement}

The authors declare no conflict of interest.

\section{References}

1 Weiler-Normann C, Schramm C, Quaas A, Wiegard C, Glaubke C, Pannicke N, Möller S, Lohse AW: Infliximab as a rescue treatment in difficult-to-treat autoimmune hepatitis. J Hepatol 2013;58:529-534.

- Yang Q Wang J, Liu R, Wang Z, Li Y, Zhang Y, Hao X, Huang Y, Xie W, Wei H: Amelioration of concanavalin A-induced autoimmune hepatitis by magnesium isoglycyrrhizinate through inhibition of CD4(+)CD25(-) CD69(+) subset proliferation. Drug Des Devel Ther 2016;10:443-453.

-3 Manns MP, Lohse AW, Vergani D: Autoimmune hepatitis--Update 2015

Muratori P, Lalanne C, Fabbri A Cassani F, Lenzi M, Muratori L: Type 1 and typ adults share the same clinical phenotype. Aliment Pharmacol Ther 2015;41:1281-1287.

5 Yuksel M, Laukens D, Heindryckx F, Van Vlierberghe H, Geerts A, Wong FS, Wen L, Colle I: Hepatitis mouse models: from acute-to-chronic autoimmune hepatitis. Int J Exp Pathol 2014;95:309-320.

6 Mieli-Vergani G, Vergani D: Autoimmune liver diseases in children - what is different from adulthood? Best Pract Res Clin Gastroenterol 2011;25:783-795.

7 Villalta D, Girolami E, Alessio MG, Sorrentino MC, Tampoia M, Brusca I Daves M, Porcelli B, Barberio G, Conte M, Pantarotto L, Bizzaro N: Autoantibody Profiling in a Cohort of Pediatric and Adult Patients With Autoimmune Hepatitis. J Clin Lab Anal 2016;30:41-46.

8 Christen U, Hintermann E: Immunopathogenic Mechanisms of Autoimmune Hepatitis: How Much Do We Know from Animal Models? Int J Mol Sci 2016;17:2007.

- 9 Hu B, Zou Y, Liu S, Wang J, Zhu J, Li J, Bo L, Deng X: Salidroside attenuates concanavalin A-induced hepatitis via modulating cytokines secretion and lymphocyte migration in mice. Mediators Inflamm 2014;2014:314081.

10 Czaja AJ, Freese DK: American Association for the Study of Liver D. Diagnosis and treatment of autoimmune hepatitis. Hepatology 2002;36:479-497.

11 Al-Chalabi T, Underhill JA, Portmann BC, McFarlane IG, Heneghan MA: Impact of gender on the long-term outcome and survival of patients with autoimmune hepatitis. J Hepatol 2008;48:140-147.

12 Gil-Farina I, Di Scala M, Salido E, Lopez-Franco E, Rodriguez-Garcia E, Blasi M, Merino J, Aldabe R, Prieto J, Gonzalez-Aseguinolaza G: Transient Expression of Transgenic IL-12 in Mouse Liver Triggers Unremitting Inflammation Mimicking Human Autoimmune Hepatitis. J Immunol 2016;197:2145-2156.

13 Yoshizawa K, Matsumoto A, Ichijo T, Umemura T, Joshita S, Komatsu M, Tanaka N, Tanaka E, Ota M, Katsuyama Y, Kiyosawa K, Abe M, Onji M: Long-term outcome of Japanese patients with type 1 autoimmune hepatitis. Hepatology 2012;56:668-676.

14 Jothimani D, Cramp ME, Mitchell JD, Cross TJ: Treatment of autoimmune hepatitis: a review of current and evolving therapies. J Gastroenterol Hepatol 2011;26:619-627.

15 Lamers MM, van Oijen MG, Pronk M, Drenth JP: Treatment options for autoimmune hepatitis: a systematic review of randomized controlled trials. J Hepatol 2010;53:191-198. 


\section{Cellular Physiology Cell Physiol Biochem 2018;46:1241-1251 \begin{tabular}{l|l} 
DOI: 10.1159/000489074 & $\begin{array}{l}\text { O 2018 The Author(s). Published by S. Karger AG, Basel } \\
\text { www.karger.com/cpb }\end{array}$ \\
\hline
\end{tabular}}

Ye et al.: Con a-Induced AIH in Mice

16 Derkow K, Loddenkemper C, Mintern J, Kruse N, Klugewitz K, Berg T, Wiedenmann B, Ploegh HL, Schott E: Differential priming of CD8 and CD4 T-cells in animal models of autoimmune hepatitis and cholangitis. Hepatology 2007;46:1155.

17 Buschenfelde KH, Kossling FK, Miescher PA: Experimental chronic active hepatitis in rabbits following immunization with human liver proteins. Clin Exp Immunol 1972;11:99-108.

18 Kuriki J, Murakami H, Kakumu S, Sakamoto N, Yokochi T, Nakashima I, Kato N: Experimental autoimmune hepatitis in mice after immunization with syngeneic liver proteins together with the polysaccharide of Klebsiella pneumoniae. Gastroenterology 1983;84:596-603.

19 Lohse AW, Manns M, Dienes HP, Meyer zum Buschenfelde KH, Cohen IR: Experimental autoimmune hepatitis: disease induction, time course and T-cell reactivity. Hepatology 1990;11:24-30.

-20 Lohse AW, Dienes HP, Meyer zum Buschenfelde KH: Suppression of murine experimental autoimmune hepatitis by T-cell vaccination or immunosuppression. Hepatology 1998;27:1536-1543.

21 Schlaak JF, Lohr H, Gallati H, Meyer zum Buschenfelde KH, Fleischer B: Analysis of the in vitro cytokine production by liver-infiltrating T cells of patients with autoimmune hepatitis.Clin Exp Immunol 1993;94:168-173.

-22 Bayer EM, Herr W, Kanzler S, Waldmann C, Meyer Zum Buschenfelde KH, Dienes HP, Lohse AW: Transforming growth factor-beta1 in autoimmune hepatitis: correlation of liver tissue expression and serum levels with disease activity. J Hepatol 1998;28:803-811.

23 Kim WH, Hong F, Radaeva S, Jaruga B, Fan S, Gao B: STAT1 plays an essential role in LPS/D-galactosamineinduced liver apoptosis and injury. Am J Physiol Gastrointest Liver Physiol 2003;285:G761-768.

24 Tiegs G, Hentschel J, Wendel A: A T cell-dependent experimental liver injury in mice inducible by concanavalin A. J Clin Invest 1992;90:196-203.

25 Tamaki S, Homma S, Enomoto Y, Komita H, Zeniya M, Ohno T, Toda G: Autoimmune hepatic inflammation by vaccination of mice with dendritic cells loaded with well-differentiated hepatocellular carcinoma cells and administration of interleukin-12 Clin Immunol 2005;117:280-293.

26 Nicoletti F, Di Marco R, Zaccone P, Salvaggio A, Magro G, Bendtzen K, Meroni P: Murine Concanavalin A-Induced Hepatitis Is Prevented by Interleukin 12 (IL-12) Antibody and Exacerbated by Exogenous IL-12 Through an Interferon-g Dependent Mechanism. Hepatology. 2000; 32:728-733.

27 Holdener M, Hintermann E, Bayer M, Rhode A, Rodrigo E, Hintereder G, Johnson EF, Gonzalez FJ, Pfeilschifter J, Manns MP, Herrath Mv, Christen U: Breaking tolerance to the natural human liver autoantigen cytochrome P450 2D6 by virus infection. J Exp Med 2008;205:1409-1422.

28 Lapierre P, Djilali-Saiah I, Vitozzi S, Alvarez F: A murine model of type 2 autoimmune hepatitis: Xenoimmunization with human antigens. Hepatology 2004;39:1066-1074.

29 Kajiya M, Sato K, Silva MJ, Ouhara K, Do PM, Shanmugam KT, Kawai T: Hydrogen from intestinal bacteria is protective for Concanavalin A-induced hepatitis. Biochem Biophys Res Commun 2009;386:316-321.

30 Wang HX, Liu M, Weng SY, Li JJ, Xie C, He HL, Guan W, Yuan YS, Gao J: Immune mechanisms of Concanavalin A model of autoimmune hepatitis. World J Gastroentero 2012;18:119-125.

-31 Sharma M, Mohapatra J, Malik U, Wagh A, Singh A, Patel HM, Pandey D, Kadam S, Shah GB, Chatterjee A, Jain MR: Selective inhibition of tumor necrosis factor-alpha converting enzyme attenuates liver toxicity in a murine model of concanavalin A induced auto-immune hepatitis. Int Immunopharmacol 2013;17:229-236.

-32 Ye TH, Yang FF, Zhu YX, Li YL, Lei Q, Song XJ, Xia Y, Xiong Y, Zhang LD, Wang NY, Zhao LF, Gou HF, Xie YM, Yang SY, Yu LT, Yang L, Wei YQ: Inhibition of Stat3 signaling pathway by nifuroxazide improves antitumor immunity and impairs colorectal carcinoma metastasis. Cell Death Dis 2017;8:e2534.

-33 Alvarez F, Berg PA, Bianchi FB, Bianchi L, Burroughs AK, Cancado EL et al: International Autoimmune Hepatitis Group Report: review of criteria for diagnosis of autoimmune hepatitis.J Hepatol 1999;31:929938.

-34 Christen U, Holdener M, Hintermann E: Animal models for autoimmune hepatitis. Autoimmun Rev 2007;6:306-311.

35 Heymann F, Hamesch K, Weiskirchen R, Tacke F: The concanavalin A model of acute hepatitis in mice. Lab Anim 2015;49:12-20.

-36 M Yüksel, D Laukens, F Heindryckx, H Van Vlierberghe, A Geerts, F Wong, Wen L, Colle I: Hepatitis mouse models: from acute-to-chronic autoimmune hepatitis. Int J Exp Path 2014;95:309-320. 


\section{Cellular Physiology Cell Physiol Biochem 2018;46:1241-1251

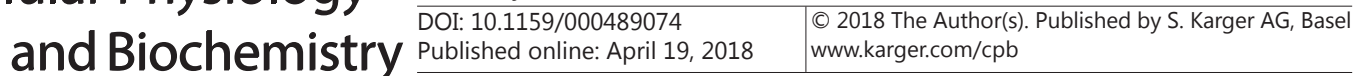

Ye et al.: Con a-Induced AIH in Mice

-37 Shen M, Lu J, Cheng P, Lin C, Dai W, Wang F,Wang C, Zhang Y, Chen K, Xu L, Zhou Y, Guo C: Ethyl Pyruvate Pretreatment Attenuates Concanavalin A-Induced Autoimmune Hepatitis in Mice. Plos one 2014; e87977.

-38 Y Ju, X Shang, Z Liu, J Zhang, Y Li, Y Shen, Liu Y, Liu C, Liu B, Xu L, Wang Y, Zhang B, Zou J: The Tim-3/ galectin-9 pathway involves in the homeostasis of hepatic Tregs in a mouse model of concanavalin A-induced hepatitis. MolImmunol 2014;58:85-91.

-39 J Xue, F Chen, J Wang, S Wu, M Zheng, H Zhu, Liu Y, He J, Chen Z: Emodin Protects Against Concanavalin A-Induced Hepatitis in Mice Through Inhibiting Activation of the p38 MAPK-NF-KB Signaling Pathway. Cell Physiol Biochem 2015;35:1557-1570.

-40 Nicoletti F, Beltrami B, Raschi E, Di Marco R, Magro G, Grasso S, Bendtzen K, Fiorelli G, Meroni PL: Protection from concanavalin A (Con A)-induced T cell-dependent hepatic lesions and modulation of cytokine release in mice by sodium fusidate. Clin Exp Immunol 1997;110:479-484.

41 Nicoletti F, Mancuso G, Cusumano V, Di Marco R, Zaccone P, Bendtzen K, Teti G: Prevention of endotoxininduced lethality in neonatal mice by interleukin-13 Eur J Immunol 1997;27:1580-1583.

42 Zaccone P, Phillips J, Conget I, Gomis R, Haskins K, Minty A, Bendtzen K, Cooke A, Nicoletti F: Interleukin-13 prevents autoimmune diabetes in NOD mice. Diabetes 1999;48:1522-1528.

43 Li H, Dai F, Peng Q Gan H, Zheng J, Xia Y, Zhang W: Myeloid-derived suppressor cells suppress CD4+ and CD8+ T cell responses in autoimmune hepatitis. Mol Med Rep 2015;3791:3667-3673.

44 Longhi MS, Ma Y, Mieli Vergani G and VerganiD: Aetiopathogenesis of autoimmune hepatitis. J autoimmun 2010;34:7-14.

45 Hegde VL, Nagarkatti PS, Nagarkatti M: Role of myeloid-derived suppressor cells in amelioration of experimental autoimmune hepatitis following activation of TRPV1 receptors by cannabidiol. PLos One 2011;6:e18281. 